Gut, $1987,28,878-882$

\title{
Distribution of the 10000 molecular weight calcium binding protein along the small and large intestine of man
}

\author{
MICHAEL STAUN \\ From the Medical Department P, Division of Gastroenterology, Rigshospitalet, Copenhagen and Department \\ of Biochemistry C, The Panum Institute, University of Copenhagen, Copenhagen, Denmark
}

SUMmaRY The distribution of the 10000 molecular weight calcium binding protein along the human small and large intestine was studied using an enzyme linked immunoadsorbent assay. Small intestinal mucosal samples were obtained from the duodenal bulb, the second and third part of the duodenum and at about $50 \mathrm{~cm}$ intervals from jejunum and ileum of five whole small intestines of necro-kidney donors. Mucosal samples of caecum, colon ascendens, and transversum were also investigated. The amount of calcium binding protein per milligram of cytosolic protein increased throughout duodenum to reach the maximum in the proximal segment of jejunum and then declined steadily to nearly undetectable levels in ileum. In the colon no 10000 molecular weight $\mathrm{CaBP}$ was detectable. The distribution of $\mathrm{CaBP}$ along the small and large intestine of man is thus parallel to the efficiency of the active calcium absorption of human intestine.

CaIcium is absorbed in the small as well as in the large intestine..$^{2}$ In the proximal segments of the small intestine calcium transport is promoted by an active mechanism, ${ }^{2}$ whereas passive absorption supervenes in the ileum and colon. ${ }^{34}$ The cellular events leading to enhanced calcium absorption, however, remains unsettled. Cytosolic calcium binding proteins (CaBP) detected in the small intestine of chicks and mammals (molecular weight 28000 and 10000 respectively) ${ }^{56}$ have been linked to the vitamin D induced calcium absorption because of correlation between the rate of calcium transport and intestinal content of $\mathrm{CaBP}$ under a variety of physiological conditions. ${ }^{78} \mathrm{CaBP}$ may furthermore play a role in maintaining intracellular calcium homeostasis. ${ }^{9}$

Only scant knowledge about the distribution of $\mathrm{CaBP}$ along the intestinal tract is available. In the rat and the pig the largest amount of $\mathrm{CaBP}$ was found in the duodenum and proximal segments of the jejunum as measured by radioimmunoassays. " "I A study

Address for correspondence: Michael Staun, Medical Department P 2131, Div of Gastroenterology. Rigshospitalet, Blegdamsvej 9, DK-21(0) Copenhagen, Denmark.

Received for publication 24 October 1986 carried out on human small intestine, however, reported a nearly constant level of $\mathrm{CaBP}$ throughout the small intestine. ${ }^{12} \mathrm{CaBP}$ has further been detected in colon epithelium of the rat by using a competitive calcium binding assay. ${ }^{13}$

The present paper reports the distribution of the 10000 molecular weight $\mathrm{CaBP}^{14}$ along the small and large intestine of man.

\section{Methods}

MATERIALS

All chemicals were obtained as previously stated. ${ }^{14}$ Specific antiserum against human intestinal $\mathrm{CaBP}$ was raised in rabbits as outlined in an earlier paper. ${ }^{14}$

TISSUE PREPARATION

All preparative steps were carried out at $4^{\circ} \mathrm{C}$.

\section{Small intestine}

Small intestine was obtained from five necro-kidney donors (age 18-55 years) within 25 minutes of death. The intestine was immediately cooled in iced $0.9 \%$ $\mathrm{NaCl}$ and then cut in pieces of $50 \mathrm{~cm}$ length and 
frozen at $-80^{\circ} \mathrm{C}$ until used. The intestine was cut open and mucosal samples were obtained by scraping from the first, second, and third part of duodenum and from the jejunum and ileum at intervals of about $50 \mathrm{~cm}$. The mucosal samples $(200 \mathrm{mg})$ were homogenised for three minutes in four volumes of $0.15 \mathrm{M}$ $\mathrm{NaCl}$ containing $0 \cdot 1 \mathrm{mmol}$ phenylmethansulphonylfluoride (PMSF) and $2.8 \mu \mathrm{g}$ aprotinin $/ \mathrm{ml}$. The homogenates were prepared by centrifugation $(50000 \times g$ for one hour at $4^{\circ} \mathrm{C}$ ) and the supernatants were removed for analysis.

\section{Colon}

A piece of normal caecum was obtained from a necro-kidney donor. Three biopsies of colon ascendens and four biopsies of colon transversum presenting a normal histological structure were obtained from patients undergoing colon resection because of ulcerative colitis or Crohn's disease. The tissue was stored at $-80^{\circ} \mathrm{C}$ until used.

A cytosol fraction of mucosa of the caecum was prepared. The mucosa $(5 \mathrm{~g})$ obtained by scraping with a microscope slide was homogenised in three volumes of $0.05 \mathrm{M}$ Tris/ $\mathrm{HC1}, \mathrm{pH} 8 \cdot 0$, containing $0.15 \mathrm{M} \mathrm{NaCl}$ and $0.1 \mathrm{mmol}$ PMSF and $2.8 \mu \mathrm{g}$ aprotinin $/ \mathrm{ml}$, using a Potter-Elvehjem homogeniser for three minutes. The homogenate was centrifuged ( $50000 \times g$ for one hour, at $4^{\circ} \mathrm{C}$ ), and the supernatant $(15 \mathrm{ml})$ was concentrated by ultrafiltration (Amicon YM 5, Lexington, MA, USA) to $2 \cdot 5 \mathrm{ml}$ and applied

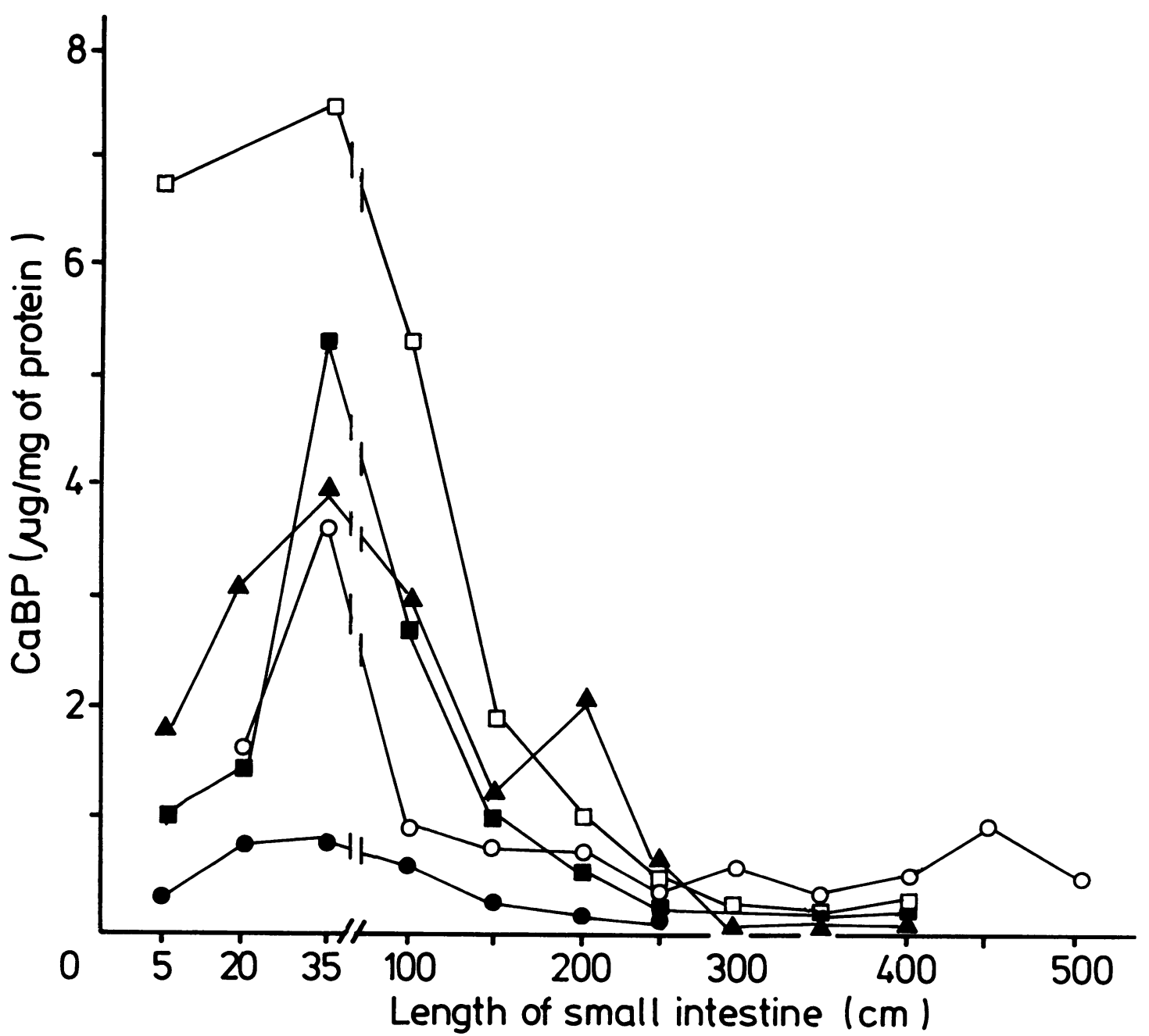

Fig. 1 Distribution of CaBP along human small intestine. A cytosol fraction of the mucosal samples was prepared as described in the Methods section. CaBP measured by the ELISA method was expressed as the $\mu g$ amount of $C$ aBP per mg of cytosolic protein. The results obtained studying five small intestines are shown in the figure. 
to a Sephadex G-100 column (size $1.5 \mathrm{~cm} \times 80 \mathrm{~cm}$ ). The column was equilibrated in and eluted with $0.05 \mathrm{M}$ Tris $/ \mathrm{HCl}, \mathrm{pH} 8.0$, containing $0.15 \mathrm{M} \mathrm{NaCl}$, at a flow rate of $3 \mathrm{ml} / \mathrm{cm}^{2}$ per hour and fractions of $2.5 \mathrm{ml}$ were collected.

Mucosal samples of colon ascendens and transversum were prepared as described for the small intestine.

\section{ASSAYS}

Protein assay

Protein was measured by a Coomassie G-250 method $^{15}$ using a commercial reagent (Bio Rad, Richmond, CA, USA) and bovine serum albumin (Cohn's fraction V) as standard.

Calcium binding assay (Chelex-100 assay)

The competitive calcium-binding assay was carried out as previously described. ${ }^{14}$

\section{Enzyme linked immunoadsorbent assay (ELISA)}

CaBP was measured by a competitive ELISAmethod carried out as previously reported. ${ }^{16}$ Purity of the human intestinal CaBP used as standard in the assay was ascertained by polyacrylamide gel electrophoresis in the presence of sodium dodecylsulphate and the specificity of the anti-CaBP antibody used was confirmed by immunoblotting experiments per- formed as earlier reported. ${ }^{16}$ All samples were tested in duplicate and the amount of CaBP per $\mathrm{mg}$ of protein was calculated. The detection limit of the assay was $3 \mathrm{ng}$ (applied in $150 \mu \mathrm{l}$ ) and the interassay coefficient of variation was about $10 \%$.

\section{Results}

SMALL INTESTINE

The distribution of immunoreactive $\mathrm{CaBP}$ along each of the five small intestines studied is shown in Figure 1. The amount of $\mathrm{CaBP} / \mathrm{mg}$ of cytosolic protein increased steeply down the duodenum to reach maximum values at a level corresponding to the third part of duodenum or proximal segments of jejunum. The maximum amount of $\mathrm{CaBP}$, however, varied significantly between individuals. Thus the highest amount of CaBP measured in each small intestine ranged from $0 \cdot 9-8 \cdot 5 \mu \mathrm{g} / \mathrm{CaBP}$ per $\mathrm{mg}$ of protein. The amount of $\mathrm{CaBP}$ gradually decreased along distal jejunum and $\mathrm{CaBP}$ was undetectable in ileum with the exception of one small intestine displaying a low CaBP level throughout ileum (Fig. 1). The cytosol fractions of the different mucosa samples were tested in several dilutions by the competitive ELISA method. The displacement curves obtained by using duodenal, jejunal or ileal extracts were parallel (not shown) thus indicating immunochemical

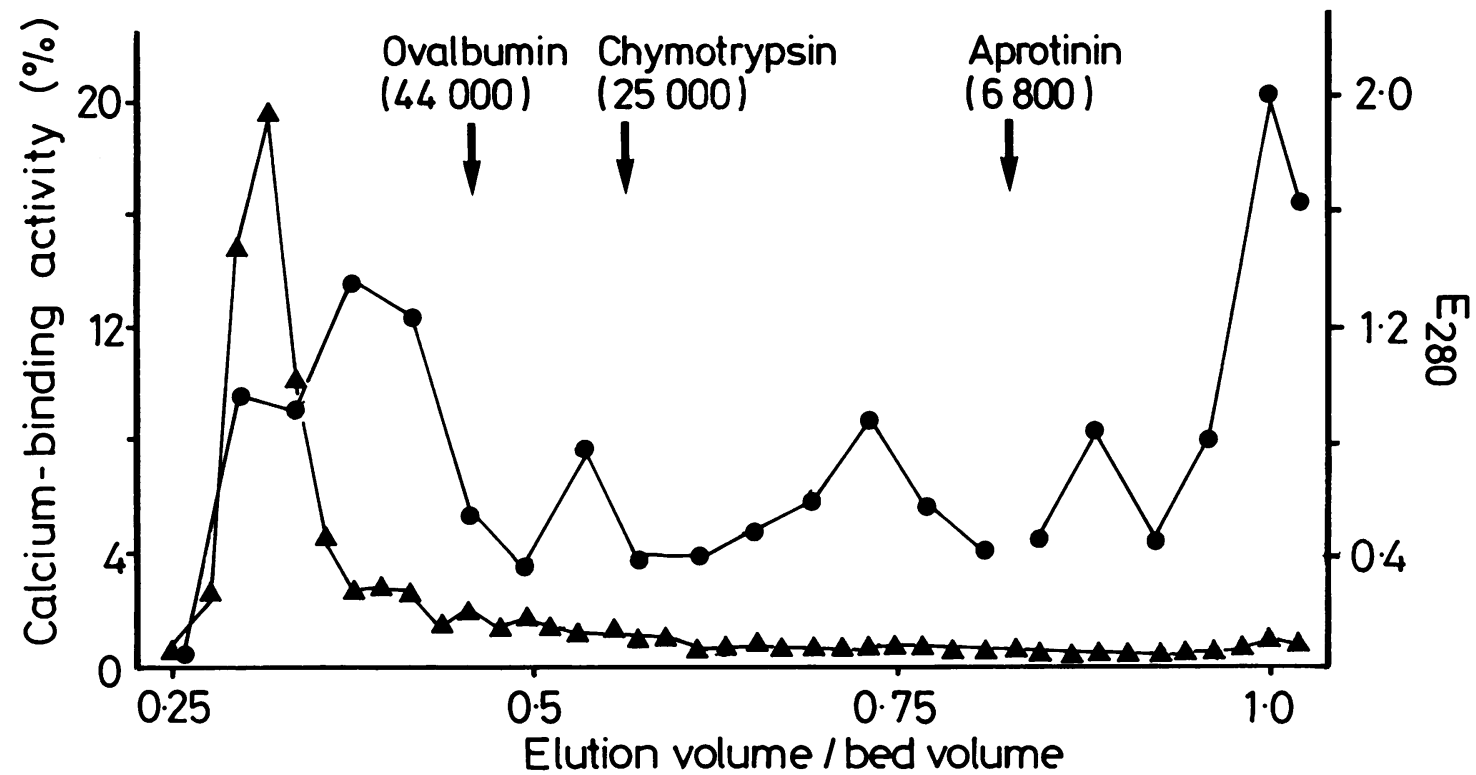

Fig. 2 Gel filtrationonow Sephadex $G-100$ of the heat precipitated cytosol fraction prepared of large intestinal mucosa. The cytosol fraction was prepared as described in the Methods section. $2.5 \mathrm{ml}$ was applied to the column. For experimental details see text. $\mathbf{\Delta}-\mathbf{\Delta}$, calcium binding activity, $\bullet-\bullet$, protein concentration $\left(E_{2 \times 0}\right)$. Positions of marker proteins is indicated by arrows (ovalbumin, 44000); chymotrypsin, 25000 ; aprotinin, 6800$)$. 
identity between CaBP detected in the different segments of the small intestine.

\section{COLON}

To investigate the expression of cytosolic calcium binding proteins in colon epithelium gel filtration of the colon cytosal was performed. The elution profile shown in Figure 2 shows that large amounts of calcium binding activity, as measured by the Chelex assay, appeared with the void volume; smaller amounts eluted in fractions corresponding to a molecular weight of about 60000 . No calcium binding activity was eluted at a lower molecular weight range (10000 to 20000$)$. Furthermore, by applying the ELISA method it was shown that no 10000 molecular weight $\mathrm{CaBP}$ was detectable in any of the fractions eluted. The presence of the 10000 molecular weight $\mathrm{CaBP}$ in the large intestine was further investigated by testing three mucosal samples of colon ascendens and four samples of colon transversum by the ELISA method. No immunoreactive $\mathrm{CaBP}$ was detected (results not shown).

\section{Discussion}

The present study shows that the level of 10000 molecular weight human small intestinal $\mathrm{CaBP}$ is highest in duodenum and proximal jejunum in accordance with the observation that the efficiency of active calcium absorption is highest in the upper segments of the small intestine. ' The study therefore supports the idea of an important role of $\mathrm{CaBP}$ in the calcium absorptive mechanism. Although the distribution of $\mathrm{CaBP}$ along the small intestine was parallel in different individuals, the amount of $\mathrm{CaBP}$ per $\mathrm{mg}$ of protein showed a considerable interindividual variation (Fig. 1). The small intestines studied were viable as judged by the specific activity of alkaline phosphatase being normal in mucosal samples of proximal jejunum (results not shown). The interindividual variations found may bear on differences in the nutritional status of the patients examined as studies performed in animal models have disclosed the level of $\mathrm{CaBP}$ to be regulated by vitamin $\mathrm{D}$ and the dietary intake of calcium and phosphate. ${ }^{171 \mathrm{~s}}$

The distribution along the human small intestine of a 28000 molecular weight CaBP has previously been investigated using immunoelectrophoresis. ${ }^{12}$ In contrast, this study reported $\mathrm{CaBP}$ to be evenly distributed throughout the small intestine of a single normal individual and of two patients with sarcoidosis. The biochemical properties of the 28000 molecular weight protein detected in the mucosal samples obtained several hours post mortem were, however, not reported. Previously, we have been unable to discover any 28000 molecular weight $\mathrm{CaBP}$ in human small intestinal mucosa $a^{14}$ and the differences displayed probably reflects that the 10000 molecular weight $\mathrm{CaBP}$ is a different protein.

Rat and pig small intestine express a 10000 molecular weight $\mathrm{CaBP}$ with molecular properties comparable with the human intestinal CaBP. ${ }^{\circ}$ Correspondingly, the distribution of $\mathrm{CaBP}$ along the small intestine of these species is to some extent similar to that of human intestinal $\mathrm{CaBP}$. Thus, using a radioimmunoassay the amount of $\mathrm{CaBP}$ was measured in mucosal samples of duodenum, midjejunum and distal-ileum of vitamin D repleted rats." A 10-30fold higher level of $\mathrm{CaBP}$ was found in duodenal mucosa as compared with jejunal and ileal mucosa containing low levels of $\mathrm{CaBP}$. Corresponding results have been reported in young pigs;" the highest amount of $\mathrm{CaBP}$ as measured by radioimmunoassay was present either in duodenum or proximal jejunum and low or undetectable levels of $\mathrm{CaBP}$ were found in ileum. In the present study, however, $\mathrm{CaBP}$ was only detected in the distal ileum of a single individual. Possibly, small amounts of $\mathrm{CaBP}$ expressed in the enterocytes of ileum remained undiscovered due to a lower sensitivity of the ELISA technique applied to measure $\mathrm{CaBP}$. The maximum levels of $\mathrm{CaBP}$ measured (about $8 \mu \mathrm{g} / \mathrm{mg}$ protein, Fig. 1) in the adult human appears to be significantly lower than reported in the young pig. "The animals investigated were not fully grown and this may account for the difference as previous studies in animals have shown a decreasing $\mathrm{CaBP}$ level with increasing age. ${ }^{17}$

In mucosal samples of caecum and colon no CaBP with a molecular weight lower than 60000 was found neither by gel filtration of colon cytosol nor by applying the ELISA method. This contrasts a previous study performed on the rat showing $\mathrm{CaBP}$ to be present in the colon epithelium as demonstrated by gel filtration of colon cytosol. Besides, the concentration of $\mathrm{CaBP}$ was parallel to the in vitro ability of the colon epithelium to transport calcium. ${ }^{13}$ A clinical significant role of colon in calcium absorption of man has been supported by the observation that patients with extensive small bowel resection had a higher fractional calcium absorption when colon was preserved. ${ }^{19}$ In addition, the calcium absorption related to colon was increased by supplying 1,25-dihydroxycholecalciferol to healthy humans ${ }^{211}$ suggesting that the 10000 molecular weight $\mathrm{CaBP}$ may be expressed in the mucosa of colon. We were, however, unable to show any presence of CaBP in mucosal samples of colon by applying the ELISA method. To exclude the possibility that CaBP of human colon epithelium have molecular properties dissimilar to $\mathrm{CaBP}$ of the small intestine, gel filtration of colon cytosol was performed. No CaBP in the 
lower molecular weight range was however detected by using the competitive calcium binding assay. The peak eluted corresponding to a molecular weight of 60000 might represent albumin also capable of binding calcium. Thus, the results of the present study argue that in patients with preserved small intestine, the expression of $\mathrm{CaBP}$ in colon mucosa do not appear to be essential for maintaining the calcium absorption of the large intestine. It is, however, possible that detectable levels of $\mathrm{CaBP}$ could be found in mucosal samples of colon from patients with severe short bowel syndrome as these patients depend more upon the calcium absorptive function of the large intestine.

The study was supported by grants from the Danish Medical Research Council (project no 12-458), P Carl Petersen's Foundation, King Christian d X's Foundation, the Foundation for the Advancement of Medical Science and the NOVO Foundation. Ms Bodil Petersen and Ms Rita Lintner are thanked for skilful technical assistance. Drs Ove Norén, Hans Sjöström and Stig Jarnum are thanked for valuable discussions of the manuscript.

\section{References}

1 Krejs GJ, Nicar MJ, Zerwekh JE, Norman DA, Kane MG, Pak CYC. Effect of 1,25-dihydroxyvitamin $\mathrm{D}_{3}$ on calcium and magnesium absorption in the healthy human jejunum and ileum. Am J Med 1983; 75: 973-6.

2 Favus MJ, Katpalia SC, Coe FL, Mond AE. Effects of diet calcium and 1,25-dihydroxyvitamin $\mathrm{D}$ on colon calcium active transport. Am J Physiol 1980; 238: G75-8.

3 Vergne-Marini P, Parker F, Pak CYC, Hull AR, DeLuca HF, Fordtran JS. Jejunal and ileal calcium absorption in patients with chronic renal disease. J Clin Invest 1976; 57: 861-6.

4 Petith MM, Schedl HP. Intestinal adaptation to dietary calcium restriction: in vivo cecal and colonic calcium transport in the rat. Gastroenterology 1976; 71 : 1039-42.

5 Wasserman $\mathrm{RH}$, Taylor $\mathrm{AN}$. Vitamin $\mathrm{D}_{3}$-induced calcium-binding protein in chick intestinal mucosa. Science 1966; 152: 791-3.

6 Fullmer CS, Wasserman RH. Isolation and partial characterization of intestinal calcium-binding proteins from the cow, pig, horse, guinca pig and chick. Biochim Biophys Acta 1975; 393: 134-42.

7 Bronner F, Lipton J, Pansu D, Buckley M, Singh R, Miller A. Molecular and transport effects of 1,25- dihydroxyvitamin $\mathrm{D}_{3}$ in rat duodenum. Fed Proc 1982; 41: $61-5$.

8 Wasserman RH, Brindak ME, Meyer SA, Fullmer CS. Evidence for multiple effects of vitamin $\mathrm{D}_{3}$ on calcium absorption: response of rachitic chicks, with or without partial vitamin $\mathrm{D}_{3}$ repletion. Proc Natl Acad Sci 1982; 79: 7939-43.

9 Glenney JR, Glenney P. Comparison of $\mathrm{Ca}^{2+}-$ regulated events in the intestinal brush border. $J$ Cell Biol 1985; 100: 754-63.

10 Thomasset M, Molla A, Parkes O, Demaille JG. Intestinal calmodulin and calcium-binding protein differ in their distribution and in effect of vitamin D steroids on their concentration. FEBS Lett 1981; 127: 13-6.

11 Arnold BM, Kuttner M, Willis DM, Hitchman AJW, Harrison JE, Murray TM. Radioimmunoassay studies of intestinal calcium-binding protein in the pig. Can $J$ Physiol Pharmacol 1975; 53: 1135-40.

12 Davie $\mathrm{M}$. Ca ${ }^{2+}$ ion-binding activity in human small intestinal mucosal cytosol. Biochem J 1981; 197: 55-65.

13 Petith MM, Wilson HD, Schedl HP. Vitamin D dependence of in vivo calcium transport and mucosal calcium binding protein in rat large intestine. Gastroenterology 1979; 76: 99-104.

14 Staun $M$, Sjöström $H$, Norén $O$. Calcium binding protein from human small intestine. Purification and properties of a 10000 molecular weight protein. Eur $J$ Clin Invest 1986; 16:468-72.

15 Bradford MM. A rapid and sensitive method for quantitation of microgram quantities of protein utilizing the principle of protein dye binding. Anal Biochem 1976; 72: 248-54.

16 Staun M. Enzyme-linked immunoadsorbent assay (ELISA) for calcium-binding protein of human small intestine. A quantitative method for measuring calciumbinding protein in small intestinal biopsies. Clin Chim Acta 1986; 159: 239-48.

17 Armbrecht HJ, Zenser TB, Gross CJ, Davis BB. Adaptation to dietary calcium and phosphorus restriction: Changes with age in the rat. Am J Physiol 1980; 239: E322-7.

18 Bruns $\mathrm{MEH}$, Fliesher EB, Avioli LV. Control of vitamin D-dependent calcium-binding protein in rat intestine by growth and fasting. J Biol Chem 1977; 252: 4145-50.

19 Hylander E, Ladefoged K, Jarnum S. The importance of the colon in calcium absorption following smallintestinal resection. Scand J Gastroenterol 1980; 15: 55-60.

20 Grinstead WC, Pak CYC, Krejs GJ. Effect of 1,25dihydroxyvitamin $\mathrm{D}_{3}$ on calcium absorption in the colon of healthy humans. Am J Physiol 1984; 247: G189-92. 